\title{
THE IMPLEMENTATION OF GROUP WORKS ON ENGLISH EDUCATION STUDENTS AT THE UNIVERSITY OF PAPUA: THE PERCEPTIONS AND PROBLEMS
}

\author{
Imelda Mallipa ${ }^{1}$ \\ UNIVERSITAS PAPUA \\ i.mallipa@unipa.ac.id ${ }^{1}$
}

Submit, 12-04-2018 Accepted, 10-06-2018 Publish, 10-06-2018

\begin{abstract}
This study aimed at investigating students' perceptions on the implementation of group works and the problems that students faced in working with their friends in group. The method of this study was mix method, descriptive quantitave and descriptive qualitative method. The participants were sixty (60) students of the first and second year students in English Education at Papua University. The data for study was taken from a five-level Linkert-scale questionnaire, open-ended questionnaire and students' reflection sheet. The results showed that some 30 $(50 \%)$ of students preferred group work to individual work and few students 12 $(20 \%)$ were disagree with group works in their learning proces while some other $18(30 \%)$ of students chose no opinion. The problems faced by students were that there were students who were difficult to interact with other tended to be passive in group discussion, those who were hinger achievers tended to dominate in group and did not listen to other opinions (sometimes did not have willingness to study together) then caused students with lower level ability had no confidence to talk in group discussion (sometimes did not come to group discussion), and students who did not want to work had no effort to read and to study materials (only asked for explanation from his/her friends). Thus, it can be concluded that the students in English Education Department at The University of Papua had positive perception on the implementation of group works in teaching process and the problems in working in group came from themselves and from their group members.
\end{abstract}

Key words: group works, the perception, the problems, higher education

\section{INTRODUCTION}

For many years, group works have been used in higher education as a learning and teaching strategy. It is believed that involving students in working with others can give many benefits for students. It can encourange students to be more indepedent and take the ownership of their own learning and can shift the emphasis from teacher-centerd to more student-centered learning. Brown 
(2001:178) stated that group works promote students responsibility and autonomy. Group works can also help students develop teamwork skills and social interactions (Payne et al., 2004:441) that are needed in social practice and improve students' achievement (Gomleksize, 2007;613, Arumugam et al., 2013:81). Furthermore, students are more motivated to achieve goal when working with others than working alone (Gillies 2003:35), students get better grades, are more satisfied with their education, and more likely to remain in college (Wasley, 2006:39).

Group works can help students learn in effective ways and give students experience to study in their own ways. However, there are some problems existing in working with others such as differences in work, communication styles, unmotivated peers, chalenges in workload management, dissatisfaction with group assessment, negative perceptions, unfavorable attitudes and emotions (Zschocke et al., 2015:359). Hence, teachers need to identify the problems in order to maximize the potential benefits of implementing group works in teaching and learning process.

This study focused on investigating students' perceptions on group work and problems that students faced in working with their friends in group. It was important to know whether the students had positive perception or negative perceptions. Previous study showed that the negative perception of students can lead to unsuccessful group collaboration (Liu et al., 2010:565). The study done by Daba, Ejersa \& Aliyi (2017:860) described that problems still occured even students had positive perceptions on group works. They found that students had misconception on objectives of group work and perceived group work as a means of getting pass mark rather than seeing it as a means of learning cooperatively through activity. The perceptions and students problems in this study were gathered by asking students to answer the questionnaire and by requiring students to make reflection in the middle and at the end of semester. The questions leading to the investigation were what was the perception of students in studying in groups and what were the problems that students faced in working with their friends in group?

\section{LITERATURE REVIEW}

Group work or working with others is a form of collaborative or cooperative learning which emphasizes the interaction among students. it is based on Vygostky' (1978:89) social constructivist theory about the importance of social interaction in the process of learning. According to Vygotsky, learning occurs in two levels: firstly on social level then on individual level. On social level, students learn by interacting with others (interpsychological) in which they learn to internalize and transform their interpresonal interaction while on individual level, 
students learn to develop their thinking skills. This theory has led teachers in higher education to activate students in learning process by working with their friends. Furthermore, in language classes, the development of communicative language teaching that demands students to talk in order to learn a language encorange many practioners and researchers conduct research on group work (Davis 1993:234 \& Barkley, Cross \& Major, 2005:209).

Research on group work done by Stevens and Slavin (1995:321) shows the effectivess of group work in increasing students'achievement and promoting the development of important life and social skills including self and mutual respect, organisation, cooperation, negotiation, flexibility, compromise, delegation, and leadership. By working with others, students can expose to many different resources and give them opportunity to accept differences. They have more time to use English to make communication with others and have experience to practice the languge. Students at university level can get positive outcomes such as helping students to deepen their understanding of the materials (Sofroniou \& Poutos, 2016:6).

The knowledge or skill that is discovered by learning from group discussion retains longer than that is received from other instructional (Beebe and Masterson, 2003:367). However, students may fail in the prosess of processing knowledge and skills in the material that they learn in group for some reasons. Some students may think that they can accomplish assigment better by themselves than in group (Elgort, Smith and Toland, 2008:195). They may not gain satisfaction from their group because they are not involved in the decision making process. Some others may rely too heavily on their group members to do the work. They do not have willingness to participate in group work and only accept the solution that is offered by others in group even it is a bad solustion to avoid conflict.

Group works can take more time than work alone (Beebe and Masterson, 2003:206). Teachers or lecturers need a good plan before implementing the group works to maximixe its potential benefits in a given time. Generally, there are four stages in group work: planning, action, monitoring, and assessment. The first stage is planning where lecturer plans goup work activities and describes it in syllabus. The second stage is action in which lecturer implements group work in teaching process. The important part of this stage is the decision of lecturer about how to assign students to a group. There are three common methods in assigning students to group: randomly assigning, instructor assigned, and self-selected groups. In randomly assigning method, students are grouped without any criteria while in instructor assigned, students may be assigned to group based on performance levels, academic strengths and weaknesses, ethnicity, and gender ( Connery, 1988:2-4) and in self-selected groups, students are given freedom to 
choose their group members. According to Davis (1993:301), randomly assigning students to group can maximixe heterogencity of group while according to Felder \& Brent, (2001:309) groups which are assigned by instructor tend to perform better than self-selected group. Self selected groups often grativate toward friends (Cresnica et al., 2002:205) that can cause students tend to socialize in group than to discuss the given material. In assigned students to group, the number of students in a group is also needed to be considered. Too many members of a group can be a problem in group work management. It is suggested that groups of four or five members tend to work best (Davis, 1993:305), three or four members are more appropriate (Cresnica at al.2002:407).

The third stage is monitor. In this stage, the lecturer monitor the groups' activities and progress throughout the semester and assess the level of involvement from each member. Lecturer should have a specific method to see the effort of the students in their learning process in group. Lecturer needs to assure that all students follow the instructions that are given and also assures that students know the learning objectives. Davis (1993:306) stated that the succsessful of group work can be achieved if students understand the purpose of the group work. Lecturer may observe and record the students progress in classroom or ask students to submit weekly progress reports in which students show the result of their particpation in group discussion. Students may use a rubric that can help lecturer to grade students performance in class/group and also can involve students to monitor their friends in group. Table 1 describes the example of rubric that can be used (Blaz, 2006:174).

Table 1 Rubric for Participation of Group/Classroom Activities

\begin{tabular}{|c|c|c|}
\hline \multicolumn{3}{|c|}{ Performance Grade } \\
\hline $9-10$ & Exceeds the standard & $\begin{array}{l}\text { Help facilitate group/classroom } \\
\text { activity } \\
\text { Demonstrates engaged, active } \\
\text { learning throughout the period } \\
\text { Makes consistently strong } \\
\text { contribution to the group/classroom }\end{array}$ \\
\hline 8 & Meets the standard & $\begin{array}{l}\text { Participates in a generally } \\
\text { constructive way } \\
\text { Demonstrates engaged, active } \\
\text { learning throught part of the class } \\
\text { period } \\
\text { Makes some strong contribution to } \\
\text { the group/classroom }\end{array}$ \\
\hline
\end{tabular}




\begin{tabular}{lll}
\hline 7 & Approaches the standard & $\begin{array}{l}\text { Has little negative or positive effect } \\
\text { on the group/class } \\
\end{array}$ \\
& May grappling with concepts but \\
& shows little evidence of learning \\
& Prepares, but makes little contribution \\
& to the group/classroom \\
\hline $5-6 \quad$ Falls below the standard & Has more of a negative effect on the \\
& class than positive \\
& Required work or preparation \\
& incomplete \\
& Distruptive behavior makes learning \\
& difficult for others \\
& Has trouble staying on task; needs to \\
& be reminded \\
\hline 0 & Fails to meet standard & Sent out of class or truant \\
& Refuses to stay on task \\
& Sleeps \\
\hline
\end{tabular}

(adopted from Blaz, 2006:175)

The fourt stage is assessment. In this stage, lecturer evaluates the process and the result of group work. what will be assessed, how it will be assessed and who will conduct the assessment must be informed to the students. Assessment decisions should be consistent with the objectives decribed in syllabus. There are a number of methods can be used includinng a shared group mark, individual marks based on product, group process and individual effort.

\section{RESEARCH METHOD}

The study was done by randomly assigned students into small groups to study a given topic. Each group had four or five members. The first and second year students in English Education at University of Papua were chosen as participants. It was thought that they still adjusted their strategies to study in university. Both groups (fist and second years student) were treated in different class with different subject to facilitate their different needs in studying materials in subject. The first year students were taught Reading I and the second year students were taught Structure III. There were 60 students in Reading I class and 16 students in Structue III class. The total number of students who participated in teaching and learning process were 76 students but only 60 students came to give response in quetionnaire. 
The process of learning in group was done outside the classroom and inside the classroom. Before the mid term examination, study in group took place outside the classroom. The students were required to study a given topic. Every week, they had to discuss the provided materials and did the exercises following. They were given freedom to decide when and where they studied in a group. The result of the discussion should be reported individualy in a log book. There was also a two-hour meeting for group presentation and discussion. A group was chosen randomly to present the materials before coming to discussion. The lecturer monitored the process of presentation and discussion and gave some explanation when it was needed. Sometimes there was a warming session at the beginning of the class to stimulate students in remembering what they had read and discussed in their group. To check the students 'understanding on materials, the test was given once in two weeks. The students took the quiz individually. After mid term examination, group works took place inside the classroom. It was based on the students' suggesstion in their reflection sheet. Most students stated that they needed the presence of lecturer in the process of study in group because they still found some problems dealing with their group members' attitudes in the process of deciding time and place to do group work and in the process of group discussion.

The materials for the first year students were taken from Active Skills Reading Students Book 1 Written by Neil J. Anderson, 2003. There are 16 Units with 2 chapters with reading text and exercises. In each unit, Text I is provided for students to develop their reading skill and text 2 is provided to develop reading fluency. The exercises following the text are reading comprehension test, vocabulary comprehension test, vocabulary skills exercises, and real life skill practice. The author of the book provides complete additional information about the topic and task activities. There is also footnote for the explanation of some terms of the topic in text.

The materials for the second year students were taken from student book provided by the lecturer. The book contains eleven (11) units with 11 topics on different concepts of English grammar in complex and compound sentences. In each unit, the topic and sub topic are introduced by giving a brief explanation of concept followed by examples and exercises in which students are required to apply the concept into English sentences. The explanation begins with the very simple concept to the difficult concept. The students were encouranged to find other sources.

The data for the study was taken from questionnaires. There were two kinds of questionnaires: a five-level Linkert-scale questionnaire and open-ended questionnaire. The statements in questionnaire was adapted from Daba et al (2017:275). The questioonaire used two langguages, English and Bahasa 
Indonesia. Before it was used, the items were validated by using the statistical software SPSS version 23. Seven (7) items out of twelve (12) items were considered as valid items to be used in this study.

\section{FINDING}

This section presents the findings and discussion on the perception of students in studying in groups and the problems that students faced in working with their friends in group.

\section{Students' perception on group works}

The table 2 showed the perception of students on group works including the students' peferences, the group works adeventages and disadventages, and the students' difficulties in working together. It was found that $30(50 \%)$ of the students preferred group works which indicated that they preferred to work together in learning process to individual work and few students $12(20 \%)$ were disagree with group work in their learning proces. Regarding the adventages and disadventages of group works, most students 50 (83.3\%) got motivation while learning in group and very few $4(6.7 \%)$ of them were not affected on their motivation during learning with their friends. Many students 41 (68.3\%) found that they learn better when they made interaction with their friends in group than with their lecture. Only few $8(13.3 \%)$ of students were disagree with the idea that they learn better from group interaction than lecture. While few $10(1.7 \%)$ students found that group grade was not fair for them, $13(21.6 \%)$ of students had no opinion and many 37 (61.7) of them were disagree with the statement about the fairness of group grade. Only very few students $5(8.4 \%)$ who thought group assignment made them unnessary busy while many 47 (78.3\%) who did not think that group assigment made them unnessary busy.

In the statement about the difficulties in working with group members, few students $11(18.4 \%)$ found difficulties in getting relevant references while some $29(48,3)$ of students had no opinion and some other $20(33.3 \%)$ of students did not get difficulties in getting relevant references. $13(21.7 \%)$ of students got difficulties in sharing members group work, $22(36.7 \%)$ of students have no opinion and $25(41.7 \%)$ of students did not get difficulties in sharing members group work. 
Table 2.The Perception of Students on Group Works

\begin{tabular}{|c|c|c|c|c|c|c|c|c|c|c|c|}
\hline \multirow{2}{*}{ No } & \multirow{2}{*}{ Statements } & \multicolumn{2}{|c|}{ SA } & \multicolumn{2}{|c|}{$\mathbf{A}$} & \multicolumn{2}{|c|}{ NO } & \multicolumn{2}{|c|}{ DA } & \multicolumn{2}{|c|}{ SDA } \\
\hline & & $\mathbf{F}$ & $\%$ & $\bar{F}$ & $\%$ & $\mathbf{F}$ & $\%$ & $\mathbf{F}$ & $\%$ & $\mathbf{F}$ & $\%$ \\
\hline 1 & $\begin{array}{l}\text { I prefer } \\
\text { group } \\
\text { works than } \\
\text { individual } \\
\text { work }\end{array}$ & 8 & 13.3 & 22 & 36.7 & 18 & 30 & 12 & 20 & 0 & 0 \\
\hline 2 & $\begin{array}{l}\text { It motivates } \\
\text { me to learn } \\
\text { from group } \\
\text { work }\end{array}$ & 23 & 38.3 & 27 & 45 & 6 & 10 & 4 & 6.7 & 0 & 0 \\
\hline 3 & $\begin{array}{l}\text { I learn } \\
\text { better from } \\
\text { group } \\
\text { interaction } \\
\text { than lecture }\end{array}$ & 11 & 18.3 & 30 & 50 & 11 & 18.3 & 6 & 10 & 2 & 3.3 \\
\hline 4 & $\begin{array}{l}\text { A group } \\
\text { grade is not } \\
\text { fair }\end{array}$ & 3 & 5 & 7 & 11.7 & 13 & 21.6 & 25 & 41.7 & 12 & 20 \\
\hline 5 & $\begin{array}{l}\text { Group } \\
\text { assignment } \\
\text { makes me } \\
\text { unnessary } \\
\text { busy }\end{array}$ & 1 & 1.7 & 4 & 6.7 & 8 & 13.3 & 23 & 38.3 & 24 & 40 \\
\hline 6 & $\begin{array}{l}\text { It is } \\
\text { difficult to } \\
\text { get relevant } \\
\text { references }\end{array}$ & 1 & 1.7 & 10 & 16.7 & 29 & 48.3 & 15 & 25 & 5 & 8.3 \\
\hline 7 & $\begin{array}{l}\text { It is } \\
\text { difficult to } \\
\text { share } \\
\text { members } \\
\text { work } \\
\text { equally }\end{array}$ & 3 & 5 & 10 & 16.7 & 22 & 36.7 & 16 & 26.7 & 9 & 15 \\
\hline
\end{tabular}

SA: Strongly disagree, A: Agree, NO: No Opinion, DA: Disagree, SDA: Strongly Disagree 


\section{The problems in Group Works}

Most students had positive perception on the implementation of group works in their learning process. Some of them took some adventages on working with other but others found some problems in learning with their friends in group. A student who got positive experience during the implementation of group work stated that she got the chance to share ideas.

"Working with friends with different level of understanding gave me chance to share ideas. When I did not understand the materials, I got to know from my friends in group and when I understood the materials that my friends did not understand, I was asked to explain to them." UH

According to the student (UH), the group work is useful for students only if all members of group have willingness to share their knowledge or work together and it does not work when some members do not want to participate actively in group discussion. A member of other group supported the statement as she stated below:

"It is useful when working with friends who want to share knowledge but it is useless when I find group members who can not be asked to work together and who have no willingness to study together." (CP)

Based on the experience of the student (CP) in learning with her group members, she found that some of her friends did not want to work together and did not have willingnes to learn together. It made her feel difficult to answers if she asked whether the group work was useful or not. Her statement was proved by a friend of her group who can not work together in group as she stated below:

"My weaknesses is I find difficult to interact with other people. It makes me difficult to find friends to work together....." SW

She (SW) admitted that she preferred individual work to group works because she thought that she could understand the topic by reading the materials. She stated that sometimes group work made her difficult in understanding the materials. She tried to find other sources and also found a tutor to help her in learning the given topic. She also stated that it was difficult to manage time to work together. Even they had made an appointment about the time for group discussion, some of group members did not come. Sometimes even they came, they did not take the discussion seriously. They sometimes talked about another topic instead of discussing the given materials.

A student who had no opinion on the statement about students' preference on group works found difficulties in involving all members in group discussion. She stated that some members of her group were passive in group discussion. Even she thought that she could understand the topic in her own way, she still agreed that group work was useful for her to improve her skills ability in sharing ideas and to develop her presentation skills.

".......It is difficult to make all the members in a group to work cooperatively and to activate the mood for all the members to work. The most important thing that is improved 
is the ability of mine to share. It also helps me to write down the explanations of the material more easily, because I can already explain it up to the group's members." NK

Based on her (NK) statements, it was implied that her friends did not undertand a topic by simply read the provided materials so she took a role as a tutor for her friend. A friend of her group confirmed that she found a good group member to whom she usually asked.

I got to work with a good friend in group. I usually asked for explanion to her and she enthusiastically gave explaination to me. Sometimes I found a friend in group who did not want to share her/his knowledge and sometimes I found a friend who did not accept the other opinions.(YH)

The student (YH) was a students with mid level abilty. She was the kind of students who had a willingness to ask when she did not understand the materials. She was different from some of students who had low ability in understanding the given materials. Although those students realized that they could not understand the given materials, they did not ask for help. A student stated she had no confidence to talk in group discussion and chose to be passive in group discussion. She found that some of her friends with hinger level ability did not want to explain to them.

\section{DISCUSSION}

Most students had positive perception on the implementation of group works in the proces of learning but the problems still occurred. It is in accordance with the previous result from the study done by Daba, Ejersa \& Aliyi (2017:862). The problems faced by students that were related to the result of Zschocke et al., (2015:378) study were the differences in work, communication styles, and unmotivated peers. Some other problems were the difficulties to get together outside their classes, lack experiences and skillls in time and team work management, in searching, evaluating and organizing evidences from various sources, sense of depending on dominant learners (Daba, Ejersa \& Aliyi, 2017:863). This present study also enlisted the low level ability of students in understanding materials as a problem. Students with lower ability encountered a problem in group discussion. Hung (2015:321) stated that students in low-level groups tended to be lower motivated learners and gave up easily when facing difficulties.

Some students had no opinion and few were disagree in statement about the implementation of group works in their learning proces for some factors that they called problems they faced along the process. The results from open-ended quetionnaire revealed that some problems came from the members of group. Some students did not have willingness to study together, were difficult to interact with others, preferred individul task, did not accept other opinion, had low or high level of ability and did not want to work (students who are lazy to study). 
Changing group members every time the students learnt a new topic was supposed to give a student experience to work with different characters and help student to deal with different problems but it did not work when students were not ready to accept the differences. The students who were difficult to interact with other tend to be passive in group discussion, students who were hinger achievers tend to dominate in group and did not want to listen to other opinion (sometimes did not have willingness to study together) then caused students with lower level ability hade no confidence to talk in group discussion, and students who did not want to work had no effort to read and study materials (only ask for explanation from his/her friend).

\section{CONCLUSION}

It can be concluded that students in English Education Department at The University of Papua had positive perception on the implementation of group work in English teaching process and the problems in working in group came from themselves and from their group members. The problems from themselves included the difficulty to interact, the lack of confidence, the low level ability, the lack of interest and the lack of motivation while factors from their group members were low participation from their friends in group, and the dominant participation of their friends who has high-level ability. This present study was the investigation of some factors that should be considered in implementating group works to maximize its benefit in teaching and learning process. The future study is recomended to find strategies to facilitate students' involvement in group discussion in order to activate the role of teachers to develop team work skills.

\section{REFERENCES}

Arumugam, N., Rafik-Galea,S., Mello, G.D., \& Dass, L.C. (2013). Cultural influences on group learning in an ESL classroom. Review of Journal Studies, 5(2), 81-89. Hhtp://dx.doi.org/105539/res.v5n2p81v.

Barkeley, E.F., Cross, K.P., \& Major. C.H. (2005) Collaborative Learning Techniques: A handbook foe college facukty. San Francisci; Jossey-Bass Publishers

Beebe, S.A., \& Masterson, J.T. (2003). Communicating in small groups. Pearson Education Inc. Boston Massachusetts.

Blaz, Deborah. (2006). Differentiated Instruction: A Guide for Foreign Language Teachers. NY: Eye on Education.

Brown, D. (2001). Teaching by Principles: an Interactive Approach to Language Pedagogy. Y: Longman.

Csernica, J., Hanyka, M., Hyde, D., Shooter., Toole, M., \& Vigeant, M. (2002). Practical guide to taemwork version 1.1. College of Engineering, Bicknell University. 
Connery, B.A. (1988). Group work and collaborative writing. Teaching at Davis, 14(1),p.2-4. (Publication of the Teaching Resourches Center, University of California at Davis)

Daba T, Ejersa, S J \& Aliyi, S. (2017). Student perception on group work and group assignments in classroom teaching: the case of Bule Hora University second year biology students, South Ethiopia: An Action Research. Educational Research and Reviews. http://www.academicjournals.org/ERR

Davis, .G. (1993). Tools for Teaching. Jossey-Bass Inc., San Francisco: California.

Elgort, I., Smith A.G., \& Toland, J. (2008). Is wiki an effective platform for group corse work? Australian Journal of Educational Technology, 24 (2), 195210.

Felder, R.M. and rent, R. (2001). Effective strategies for cooperative learning. Journal of Cooperation \& Collaboration in College Teaching, 10(2), 6975).

Gillies, R.M. (2003). Structuring cooperative group work in classrooms. International Journal of Educational Research, 39, 35-49

Gomleksize, M.N. (2007). Effectiveness of cooperative learning (Jigsaw II) method in teaching english as a foreign language to engineering students (case of Firat University, Turkey). European Journal of Engineering Education, $32(5)$, 613-625). http://dx.doi.org/10.1080/03043790701433343

Hung, Yu-Ju. (2015). Practice of Differentiated Instruction and Alternative Assessments with Young EFL Learners in Taiwan. Tesol International Journal, Vol. 10 Issue 2.

Liu, S., Joy, M.,\& Griffiths, N. (2010) Students' perceptions of the factors leading to unsuccessful group collaboration. 2010 10th IEEE International Confrence on Adbanced Learning Technologies. Oro.open.ac.uk/42138/1/liu_joy-griffiths_icalt10..pdf

Payne, B.K., Monl-Turner, E., Smith, D.,\& Sumter, D. (2004). Improving group work: voices of students. Education, 126 (3), P. 441-448.

Steven, R.J. \& Slavin, R (1995). The Cooperative Elementary School: Effects on Student's Achievement, Attitudes and School Relations. American Educational Research Journal 32 (2), 321-351

Sofroniou, A., \& Poutos, Konstantinos. (2016). Investigating The Effectiveness of Group Work in Mathematics. Educ.Sci.2016,6,30. http://www.mdpi.com>pdf

Vygotsky, L.S. (1978). Mind in Society: The development of hinger prsychological processes. Cambridge, MA: MIT Press.

Wasley, P. (2006). Underrepresented students benefit most from engagement. The chronicle of Hinger Education, 53 (13), p.A39

Zschocke, K., Wosnitza, M., \& Bürger, K. (2016). Emotions in group work: insights form an appraisal-oriented perspective. Eur J Psychol Educ (2016) 31:359-384. DOI 10.1007/s10212-015-0278-1 